\title{
Hubungan Pengetahuan Ibu tentang Gizi dan Asupan Makan Balita dengan Status Gizi Balita (BB/U) Usia 12-24 Bulan
}

\section{Association Mother's Nutrition Knowledge and Toddler's Nutrition Intake with Toddler's Nutritional Status (WAZ) at the Age 12-24 Months}

\author{
Nindyna Puspasari*1, Merryana Andriani ${ }^{1}$
}

\begin{abstract}
ABSTRAK
Latar Belakang: Masa balita merupakan suatu periode penting dalam tumbuh kembang anak karena masa balita yang akan menentukan perkembangan anak di masa selanjutnya. Ketepatan pemberian makan pada balita dapat dipengaruhi oleh pengetahuan ibu tentang gizi karena ibu sebagai tombak dalam penyedia makanan untuk keluarga. Selain pengetahuan ibu tentang gizi, tingkat asupan makan balita juga dapat secara langsung mempengaruhi status gizi balita tersebut.

Tujuan: Penelitian ini bertujuan mengetahui hubungan pengetahuan ibu tentang gizi dan asupan makan balita dengan status gizi balita (BB/U) usia 12-24 bulan.

Metode: Penelitian ini merupakan penelitian observasional analitik dengan desain cross-sectional dan dilakukan di wilayah kerja Puskesmas Tambak Wedi Kecamatan Kenjeran Kota Surabaya pada bulan Juli 2017. Sampel penelitian yaitu balita usia 12-24 bulan sebanyak 47 balita. Variabel independen yang diteliti adalah karakteristik ibu (usia, pekerjaan, pendidikan dan pendapatan keluarga), pengetahuan ibu tentang gizi, dan asupan makan balita (energi, karbohidrat, protein dan lemak). Variabel dependen yang diteliti adalah status gizi balita (BB/U). Pengumpulan data dilakukan menggunakan metode wawancara dengan kuesioner recall $2 \times 24$ jam untuk mengetahui asupan makan balita dan pengukuran berat badan balita.

Hasil: Penelitian menunjukkan bahwa sebagian besar ibu balita memiliki pengetahuan tentang gizi yang baik dengan status gizi balita normal $(81,8 \%)$ dan yang memiliki pengetahuan kurang dengan status gizi balita tidak normal $(92,9 \%)$. Hasil uji statistik chi square menunjukkan adanya hubungan antara pengetahuan ibu $(p=0,000)$, asupan energi $(p=0,008)$, asupan karbohidrat $(p=0,024)$ dan asupan protein balita $(p=0,002)$ dengan status gizi balita $(B B / U)$. Namun, tidak terdapat hubungan antara karakteristik ibu dan asupan lemak balita $(p=0,175)$ dengan status gizi balita $(B B / U)$.

Kesimpulan: Status gizi balita dipengaruhi oleh pengetahuan ibu tentang gizi dan asupan makan balita (energi, karbohidrat dan protein). Oleh karena itu, diperlukan peningkatan pengetahuan ibu tentang gizi melalui penyuluhan dan peningkatan asupan makan balita (energi, karbohidrat dan protein).
\end{abstract}

Kata Kunci: asupan makan, balita, pengetahuan ibu, status gizi 


\begin{abstract}
Background: Toddler is an important period in child growth that will determine the future development. The accuracy of toddler feeding is affected by mother's knowledge of nutrition, considering mother as the main food provider for family. Besides, nutrition intake of toddler could also affected nutritional status.

Objectives: This study aimed to determine associated of mother's nutrition knowledge and toddler's nutrition intake with toddler's nutritional status (WAZ) at the age 12-24 months.

Methods: This study was an observational analytic research with cross-sectional design in Tambak Wedi Village, Kenjeran Sub District, Surabaya done in July 2017. The sample was 47 toddlers at the age of 12-24 months. The independent variables were mother's characteristic (age, employment, education, family income), mother's nutritional knowledge, and toddler's nutrition intake (calories, carbohydrate, protein and fat). The dependent variable was toddler's nutritional status. The data collected by interview used questionnaire such as $2 \times 24$ hours food recall for toddler's intake nutrition, and weight measurement.

Results: The result showed that most of respondents have good knowledge with normal nutritional status (81.8\%) and respondents have less knowledge with unnormal nutritional status (92.9\%). The result of chi square test showed that there was a relation between mother's knowledge $(p=0.000)$, toddler's calori $(p=0.008)$, carbohydrate $(p=0.024)$ and protein intake $(p=0.002)$. Meanwhile, there was no association between characteristic of motherand fat intake $(p=0.175)$ with nutritional status (WAZ).

Conclusions: The conlusion of this study is toddler's nutritional status influenced by mother's knowledge about nutrition and toddler's nutrition intake. Therefore, it is necessary to increase mother's knowledge about nutrition through counseling and increase toddler's nutrition intake (calories, carbohydrate and protein).
\end{abstract}

Keywords: nutrition intake, toddler, mother's knowledge, nutritional status

\footnotetext{
*Koresponden:

nindyna.puspasari@gmail.com

${ }^{1}$ Departemen Gizi Kesehatan, Fakultas

Kesehatan Masyarakat-Universitas Airlangga
}

\section{PENDAHULUAN}

Golden age (periode emas) merupakan periode yang sangat penting sejak janin sampai usia dua tahun. Pada dua tahun pertama kehidupan tersebut terjadi proses pertumbuhan dan perkembangan tubuh yang dimulai sejak janin. Jika pemenuhan gizi pada masa tersebut baik, maka proses pertumbuhan dan perkembangan dapat optimal. Jika kebutuhan zat gizi kurang maka dapat berisiko menimbulkan gangguan pertumbuhan dan perkembangan pada seluruh organ dan sistem tubuh sehingga akan berdampak pada masa yang akan datang ${ }^{1}$.
Status gizi adalah keadaan pada tubuh manusia yang merupakan dampak dari makanan dan penggunaan zat gizi yang dikonsumsi seseorang. Status gizi dapat dibagi menjadi beberapa indikator, diantaranya adalah indikator Berat Badan menurut Umur (BB/U) sehingga dapat dibedakan menjadi 4 kategori yaitu gizi buruk, gizi kurang, gizi baik dan gizi lebih².

Berdasarkan sifat indeks berat badan menurut umur (BB/U) diatas, maka pada penelitian ini menggunakan indikator berat badan menurut umur (BB/U) karena indikator tersebut dapat menggambarkan status gizi seseorang saat ini. Selain itu, penggunaan 
indikator berat badan menurut umur $(\mathrm{BB} / \mathrm{U})$ karena indikator tersebut lebih mudah dan lebih cepat dimengerti oleh masyarakat umum sehingga dengan mudah dapat dilakukan, sensitif untuk melihat perubahan status gizi jangka pendek dan dapat mendeteksi kegemukan ${ }^{3}$.

Kelompok usia yang menjadi perhatian penting karena sering mengalami rawan gizi selain ibu hamil, ibu menyusui dan lanjut usia adalah balita. Masa balita merupakan periode yang penting karena pada masa tersebut terjadi pertumbuhan yang pesat diantaranya adalah pertumbuhan fisik, perkembangan psikomotorik, mental dan sosial yang dialami balita tersebut. Usia 0-24 bulan merupakan periode emas karena pada masa tersebut terjadi pertubuhan dan perkembangan yang pesat, tetapi pada usia 0-24 bulan tersebut juga merupakan periode kritis. Periode emas dapat terjadi apabila pada usia tersebut, balita memperoleh asupan gizi yang sesuai bagi tumbuh kembangnya. Periode kritis dapat terjadi apabila saat usia tersebut, balita tidak memperoleh asupan atau makanan sesuai kebutuhan gizinya sehingga dapat mengakibatkan tumbuh kembang yang terhambat. Tumbuh kembang yang terhambat tersebut dapat terjadi pada saat itu dan juga pada waktu selanjutnya atau pada saat dewasa ${ }^{4}$.

Oleh karena itu, balita sebaiknya mendapatkan perhatian yang lebih dari orangtua karena balita termasuk dalam kelompok usia yang memiliki risiko tinggi. Masalah gizi yang dapat terjadi pada balita adalah tidak seimbangnya antarajumlah asupan makan atau zat gizi yang diperoleh dari makanan dengan kebutuhan gizi yang dianjurkan pada balita misalnya Kekurangan Energi Protein (KEP). Hal tersebut dapat mempengaruhi status gizi balita dan akan menunjukkan status gizi kurang atau buruk pada balita.

Berdasarkan Riskesdas (2013), prevalensi gizi kurang secara nasional bersifat fluktuatif karena pada tahun 2007 prevalensi gizi kurang $18,4 \%$ dan mengalami penurunan pada tahun 2010 yaitu 17,9\%, tetapi pada tahun 2013 prevalensi gizi kurang mengalami peningkatan kembali $19,6 \%$ yang terdiri dari
$13,9 \%$ gizi kurang dan $5,7 \%$ gizi buruk. Prevalensi berat badan kurang di Jawa Timur adalah $19,1 \%$ dan jika dibandingkan dengan tingkat nasional (19,6\%) termasuk dalam masalah kesehatan masyarakat tingkat sedang. Berdasarkan data Dinas Kesehatan Provinsi Jawa Timur, masalah gizi kurang juga bersifat fluktuatif. Pada tahun 2012, prevalensi gizi kurang sebesar 12,6\%, tahun 2013 sebesar $12,1 \%$ dan tahun 2014 sebesar $12,3 \%^{5}$.

Berdasarkan Data Operasi Timbang Tahunan Puskesmas Tambak Wedi (2015), prevalensi underweight pada balita usia 12-24 bulan sebesar $15,65 \%$ dan mengalami peningkatan pada tahun 2016 menjadi 21,11\%. Berdasarkan data tersebut menunjukkan bahwa di wilayah kerja Puskesmas Tambak Wedi merupakan daerah yang mengalami peningkatan kejadian gizi kurang pada balita di wilayah Surabaya.

Menurut Prawirohartono dalam Wahyuni menyebutkan bahwa status gizi balita dapat dipengaruhi oleh 2 faktor yaitu faktor langsung dan tidak langsung. Faktor langsung yang dapat mempengaruhi status gizi adalah penyakit infeksi dan asupan makan, sedangkan faktor tidak langsung yang dapat mempengaruhi status gizi adalah pengetahuan ibu tentang gizi, usia penyapihan, berat bayi lahir rendah (BBLR), pemberian makanan terlalu dini, besar keluarga, pola asuh anak, kesehatan lingkungan dan pelayanan kesehatan ${ }^{6}$.

Salah satu faktor yang dapat mempengaruhi asupan makan seseorang adalah pengetahuan gizi yang akan berpengaruh terhadap status gizi seseorang. Pengetahuan gizi adalah pengetahuan terkait makanan dan zat gizi. Sikap dan perilaku ibu dalam memilih makanan yang akan dikonsumsi oleh balita dipengaruhi oleh berbagai faktor, diantaranya adalah tingkat pengetahuan seseorang tentang gizi sehingga dapat mempengaruhi status gizi seseorang tersebut. Pengetahuan gizi ibu yang kurang dapat menjadi salah satu penentu status gizi balita karena menentukan sikap atau perilaku ibu dalam memilih makanan yang akan dikonsumsi oleh balita serta pola makan terkait jumlah, jenis dan frekuensi yang akan mempengaruhi asupan makan pada bayi tersebut. 
Pengetahuan gizi ibu dapat dipegaruhi oleh usia, pendidikan, pengetahuan, pekerjaan dan pendapatan. Selain itu, asupan makan pada balita juga dipengaruhi oleh budaya setempat yang juga dapat mempengaruhi pemilihan makanan oleh ibu'. Oleh karena itu, jika seorang ibu memiliki pengetahuan gizi yang kurang maka asupan makanan yang akan diberikan kepada balita juga kurang tepat dan dapat mempengaruhi status balita tersebut.

$$
\text { Penelitian Kurniawati }
$$
menyebutkan bahwa terdapat hubungan tingkat pengetahuan ibu tentang gizi dengan status gizi balita di Kelurahan Baledono. Selain itu, penelitian Wahyuni (2009) juga menyebutkan bahwa terdapat hubungan pengetahuan ibu tentang gizi dengan status gizi balita serta penelitian Wagi (2015) menyebutkan bahwa terdapat hubungan tingkat pengetahuan ibu dengan status gizi anak 0-2 tahun di Puskesmas Keputih Surabaya.

Tujuan dari penelitian ini yaitu untuk mengetahui hubungan karakteristik ibu balita (usia, pekerjaan, pendidikan, dan pendapatan keluarga), pengetahuan ibu dan asupan makan balita (energi, karbohidrat, protein dan lemak) dengan status gizi balita (BB/U).

\section{METODE}

Penelitian ini merupakan penelitian observasional analitik dengan desain crosssectional. Penelitian ini dilakukan pada Bulan Juli 2017 di wilayah kerja Puskesmas Tambak Wedi Kecamatan Kenjeran Kota Surabaya. Populasi dalam penelitian ini yaitu seluruh balita usia 12-24 bulan yang tinggal di wilayah kerja Puskesmas Tambak Wedi dengan total jumlah 267 baduta. Sampel dalam penelitian ini dipilih secara acak menggunakan teknik simple random sampling sebanyak 47 responden berdasarkan rumus Slovin. Sampel dalam penelitian harus memenuhi kriteria inklusi dan ekslusi. Kriteria inklusi pada penelitian ini yaitu balita diasuh oleh ibu kandung, bertempat tinggal di wilayah kerja Puskesmas Tambak Wedi dan rutin melakukan penimbangan pada posyandu di wilayah kerja Puskesmas Tambak Wedi. Kriteria ekslusi pada penelitian yaitu balita sedang mengalami penyakit infeksi.

Variabel dependent dalam penelitian ini adalah status gizi balita (BB/U). Pengukuran berat badan balita menggunakan digital scale dengan ketelitian $1,0 \mathrm{~kg}$. Hasil pengukuran di entry kedalam software WHO Anthro versi 3.0.1. kemudian dapat diketahui nilai Z-score pengukuran status gizi berat badan menurut umur. Nilai Z-score dibedakan menjadi dua yaitu status gizi normal dan status gizi tidak normal. Status gizi normal yaitu status gizi baik (-2 SD sampai +2 SD). Status gizi tidak normal terdiri dari status gizi buruk ( $\leq-3 \mathrm{SD})$ ), kurang $<$ $-2 \mathrm{SD}$ ), dan lebih (>2 SD). Variabel independent dalam penelitian ini adalah karakteristik ibu (usia, pendidikan, pekerjaan dan pendapatan keluarga), pengetahuan ibu tentang gizi dan tingkat asupan makan balita (energi, karbohidrat, protein dan lemak). Penelitian ini menggunakan data primer yaitu pengukuran berat badan balita dan wawancara menggunakan kuesioner untuk mengetahui karakteristik ibu dan recall 2×24 jam selama 3 hari dan tidak berturut-turut yang akan menggambarkan tingkat kecukupan zat gizi balita, sedangkan data sekunder dalam penelitian ini adalah jumlah balita usia 12-24 bulan di wilayah kerja Puskesmas Tambak Wedi Surabaya. Penilaian pengetahuan ibu menggunakan kuesioner tertutup, terdiri dari 15 pertanyaan tentang gizi yang telah diuji validitas dan reliabilitasnya dengan metode perhitungan total jawaban yang benar dibagi dengan total soal dan dikali seratus persen ${ }^{8}$. Penentuan kategori dibagi menjadi dua yaitu pengetahuan kurang dan baik. Berdasarkan Gibson (2005) hasil recall 2x24 jam selama 3 hari tersebut kemudian diklasifikasikan menjadi dua yaitu adekuat $(\geq 77 \%)$ dan inadekuat $(<77 \%)$.

Teknik pengolahan dan analisis data dalam penelitian ini menggunakan uji chi square yang bertujuan untuk mengetahui hubungan pengetahuan ibu tentang gizi dan asupan makan balita dengan status gizi balita $(B B / U)$. Penelitian ini telah mendapatkan persetujuan dari Komisi Etik Fakultas Kesehatan Masyarakat dengan nomor 323KEPK yang dikeluarkan pada tanggal 13 Juni 2017. 


\section{HASIL DAN PEMBAHASAN}

Karakteristik ibu balita usia 12-24 bulan terdiri dari usia, pendidikan, pekerjaan dan pendapatan keluarga yang dikelompokkan pada kelompok status gizi normal dan tidak normal. Berdasarkan usia, $48,9 \%$ ibu balita berusia 26-35 tahun. Jika dikelompokkan sesuai dengan status gizi balita usia 12-24 bulan, ibu yang berusia kurang dari 35 tahun lebih banyak memiliki balita dengan status gizi normal $(80,8 \%)$ jika dibandingkan dengan ibu yang berusia diatas 35 tahun $(19,2 \%)$.

Hasil analisis menggunakan uji chisquare dengan nilai $p=0,472(p>0,05)$ yang menunjukkan bahwa tidak ada hubungan signifikan antara usia ibu balita dengan status gizi balita. Hal ini sejalan dengan penelitian sebelumnya yang menyebutkan bahwa tidak terdapat hubungan antara usia ibu dengan status gizi pada balita ${ }^{9}$. Usia ibu merupakan salah satu faktor secara tidak langsung yang dapat mempengaruhi status gizi pada balita. Hal ini dapat terjadi karena faktor lain, misalnya pengetahuan ibu karena dalam penelitian ini usia ibu masih tergolong muda (< 35 tahun) sehingga ibu balita yang masih muda belum memiliki pengetahuan tentang gizi yang cukup pada saat hamil maupun pasca melahirkan ${ }^{10}$.

Status pekerjaan ibu merupakan pekerjaan yang memberikan penghasilan dalam keluarga. Status pekerjaan ibu dalam penelitian ini diklasifikasikan menjadi 5 yaitu tidak bekerja, bekerja sebagai pegawai, wiraswasta, petani/nelayan/buruh, dan lainnya. Berdasarkan pekerjaan ibu, 82,9\% ibu balita yang tidak bekerja sedangkan ibu yang bekerja sebesar $17,1 \%$. Jika dikelompokkan sesuai dengan status gizi balita usia 12-24 bulan, ibu yang tidak bekerja lebih banyak memiliki balita dengan status gizi normal $(55,3 \%)$ jika dibandingkan dengan ibu yang memiliki balita dengan status gizi tidak normal (27,6\%).

Hasil analisis menggunakan uji chisquare dengan nilai $p=0,455(p>0,05)$ menunjukkan bahwa tidak ada hubungan signifikan antara status pekerjaan ibu dengan status gizi balita. Hal ini sejalan dengan penelitian yang menyebutkan bahwa tidak terdapat hubungan antara pekerjaan ibu dengan status gizi balita ${ }^{11}$. Pekerjaan ibu tidak berhubungan dengan status gizi balita $(B B / U)$ karena sebagian besar ibu tidak bekerja. Pekerjaan ibu dapat dipengaruhi tingkat pendidikannya. Semakin tinggi tingkat pendidikan maka kesempatan untuk mendapatkan pekerjaan juga semakin besar. Jenis pekerjaan juga akan berpengaruh pada pendapatan keluarga. Jika pendapatan keluarga tinggi maka ibu cenderung meningkatkan kualitas konsumsi pangan pada anggota keluarganya tetapi jika pendapatan keluarga rendah ibu hanya akan meningkatkan kualitas pangan padat energi. Sehingga akan berpengaruh pada status gizi balitanya.

Pendidikan ibu merupakan pendidikan terakhir yang telah ditempuh ibu balita. Berdasarkan pendidikan ibu, $42,5 \%$ ibu balita yang memiliki tingkat pendidikan terakhir SD/MI. Jika dikelompokkan sesuai dengan status gizi balita usia 12-24 bulan, ibu yang memiliki tingkat pendidikan terakhir SD/MI dengan status gizi balita normal $(25,5 \%)$ lebih banyak jika dibandingkan dengan ibu yang memiliki tingkat pendidikan terakhir SD/MI dengan status gizi balita tidak normal (17,0\%). Tingkat pendidikan seseorang memegang peran yang penting dalam kesehatan masyarakat. Orangtua yang memiliki pendidikan tinggi cenderung memilih makanan dengan gizi seimbang dan memperhatikan kebutuhan gizi anak ${ }^{12}$.

Pendapatan keluarga diklasifikasikan berdasarkan tingkatan yaitu kuartil 1 (Rp. 500.000 - Rp. 1.500.000), kuartil 2 (Rp. 1.500.001 - Rp. 2.500.000), kuartil 3 (Rp. 2.500.001 - Rp. 3.500.000), kuartil 4 (Rp. 3.500.001 - Rp. 4.500.000) dan kuartil 5 (Rp. 4.500.001 - Rp. 5.500.000). Berdasarkan pendapatan keluarga, $51,1 \%$ pendapatan keluarga termasuk dalam kuartil 2. Jika dikelompokkan sesuai dengan status gizi balita usia 12-24 bulan, pendapatan keluarga dengan status gizi balita normal 31,9\% lebih banyak jika dibandingkan dengan yang memiliki status gizi balita tidak normal (19,2\%). Hasil analisis selanjutnya juga menunjukkan bahwa tidak terdapat hubungan antara pendapatan keluarga dengan status gizi balita (BB/U) $(p=0,553)$. 
Tabel 1. Karakteristik Ibu Balita

\begin{tabular}{|c|c|c|c|c|c|c|c|}
\hline \multirow{2}{*}{ Variabel } & \multicolumn{2}{|c|}{ Normal } & \multicolumn{2}{|c|}{ Tidak Normal } & \multicolumn{2}{|c|}{ Total } & \multirow{2}{*}{ P Value } \\
\hline & $\mathbf{n}$ & $\%$ & $\mathbf{n}$ & $\%$ & $\mathbf{n}$ & $\%$ & \\
\hline \multicolumn{8}{|l|}{ Usia Ibu } \\
\hline $17-25$ tahun & 11 & 23,4 & 4 & 8,5 & 15 & 31,9 & \\
\hline $26-35$ tahun & 16 & 34,0 & 7 & 14,9 & 23 & 48,9 & \\
\hline $36-45$ tahun & 6 & 12,8 & 2 & 4,3 & 8 & 17,1 & 0,472 \\
\hline $46-55$ tahun & 0 & 0,0 & 1 & 2,1 & 1 & 2,1 & \\
\hline \multicolumn{8}{|l|}{ Pekerjaan Ibu } \\
\hline Tidak Bekerja & 26 & 55,3 & 13 & 27,6 & 39 & 82,9 & \\
\hline Pegawai & 2 & 4,3 & 0 & 0,0 & 2 & 4,3 & \\
\hline Wiraswasta & 5 & 10,7 & 1 & 2,1 & 6 & 12,8 & 0,455 \\
\hline Petani/nelayan/buruh & 0 & 0,0 & 0 & 0,0 & 0 & 0,0 & \\
\hline Lainnya & 0 & 0,0 & 0 & 0,0 & 0 & 0,0 & \\
\hline \multicolumn{8}{|l|}{ Pendidikan Ibu } \\
\hline Tidak Sekolah & 0 & 0,0 & 0 & 0,0 & 0 & 0,0 & \\
\hline Tidak tamat SD/MI & 0 & 0,0 & 1 & 2,1 & 1 & 2,1 & \\
\hline Tamat SD/MI & 12 & 25,5 & 8 & 17,0 & 20 & 42,5 & \\
\hline Tamat SMP/MTs & 7 & 14,9 & 3 & 6,4 & 10 & 21,3 & 0,214 \\
\hline Tamat SMA/MA/SMK & 12 & 25,5 & 2 & 4,3 & 14 & 29,8 & \\
\hline Tamat Perguruan Tinggi & 2 & 4,3 & 0 & 0,0 & 2 & 4,3 & \\
\hline \multicolumn{8}{|l|}{ Pendapatan Keluarga } \\
\hline Kuartil 1 & 7 & 14,9 & 3 & 6,4 & 10 & 21,3 & \\
\hline Kuartil 2 & 15 & 31,9 & 9 & 19,2 & 24 & 51,1 & \\
\hline Kuartil 3 & 10 & 21,2 & 2 & 4,3 & 12 & 25,5 & 0,553 \\
\hline Kuartil 4 & 0 & 0,0 & 0 & 0,0 & 0 & 0,0 & \\
\hline Kuartil 5 & 1 & 2,1 & 0 & 0,0 & 1 & 2,1 & \\
\hline
\end{tabular}

Tabel 2. Pengetahuan Ibu, Asupan Zat Gizi Balita (Energi, Karbohidrat, Protein dan Lemak)

\begin{tabular}{|c|c|c|c|c|c|c|c|}
\hline \multirow{2}{*}{ Variabel } & \multicolumn{2}{|c|}{ Normal } & \multicolumn{2}{|c|}{ Tidak Normal } & \multicolumn{2}{|c|}{ Total } & \multirow{2}{*}{$\begin{array}{c}P \\
\text { Value }\end{array}$} \\
\hline & $\mathrm{n}$ & $\%$ & $\mathrm{n}$ & $\%$ & $\mathbf{n}$ & $\%$ & \\
\hline Pengetahuan Ibu & & & & & & & 0,000 \\
\hline Baik & 27 & 81,8 & 1 & 7,1 & 28 & 59,6 & \\
\hline Kurang & 6 & 18,2 & 13 & 92,9 & 19 & 40,4 & \\
\hline Asupan Energi & & & & & & & 0,008 \\
\hline Inadekuat & 16 & 34,0 & 14 & 29,8 & 30 & 63,8 & \\
\hline Adekuat & 17 & 36,2 & 0 & 0,0 & 17 & 36,2 & \\
\hline Asupan Karbohidrat & & & & & & & 0,024 \\
\hline Inadekuat & 18 & 38,3 & 14 & 29,8 & 32 & 68,1 & \\
\hline Adekuat & 15 & 31,9 & 0 & 0,0 & 15 & 31,9 & \\
\hline Asupan Protein & & & & & & & 0,002 \\
\hline Inadekuat & 5 & 10,6 & 9 & 19,2 & 14 & 29,8 & \\
\hline Adekuat & 28 & 59,6 & 5 & 10,6 & 33 & 70,2 & \\
\hline Asupan Lemak & & & & & & & 0,175 \\
\hline Inadekuat & 21 & 44,7 & 12 & 25,5 & 33 & 70,2 & \\
\hline Adekuat & 12 & 25,5 & 2 & 4,3 & 14 & 29,8 & \\
\hline
\end{tabular}


Pendapatan keluarga yang rendah, akan mempengaruhi ketersediaan dan akses pangan keluarga. Jika hal tersebut terjadi, maka secara tidak langsung pendapatan keluarga dapat mempengaruhi status gizi anggota keluarga khususnya balita karena asupan yang dikonsumsi tidak mencukupi atau tidak sesuai dengan kebutuhan ${ }^{13}$. Keluarga yang memiliki pendapatan yang tinggi cenderung memiliki pengeluaran terhadap pangan yang besar jika dibandingkan dengan keluarga yang memiliki pendapatan rendah baik dari segi kualitas maupun kuantitas makanan tersebut. Namun, jika pendapatan suatu keluarga tinggi tetapi pengetahuan ibu tentang gizi kurang maka pengeluaran terhadap pangan dalam keluarga tersebut hanya didasarkan pada pertimbangan selera tanpa mempertimbangkan kebutuhan gizi balita tersebut ${ }^{14}$.

Menurut Notoatmodjo pengetahuan ibu diklasifikasikan menjadi 2 bagian yaitu kurang $(<75 \%)$ dan baik $(\geq 75 \%)$. Berdasarkan pengetahuan ibu, 59,6\% ibu balita memiliki pengetahuan tentang gizi yang baik dan $40,4 \%$ ibu memiliki pengetahuan tentang gizi yang kurang. Jika dikelompokkan sesuai dengan status gizi balita usia 12-24 bulan, ibu yang memiliki pengetahuan tentang gizi dengan status gizi balita normal $(57,5 \%)$ lebih banyak jika dibandingkan dengan ibu yang memiliki pengetahuan tentang gizi dengan status gizi balita tidak normal $(2,1 \%)$. Pengetahuan ibu tentang gizi memiliki hubungan dengan status gizi balita $(B B / U)$, dengan nilai $p=0,00(p<0,05)$. Hal ini sejalan dengan penelitian yang menyebutkan bahwa pengetahuan ibu memiliki hubungan dengan status gizi balita dengan nilai $p=0,026^{15}$.

$$
\text { Perilaku ibu ditentukan oleh }
$$

pengetahuannya mengenai suatu hal. Penelitian sebelumnya menunjukkan bahwa sebagian besar ibu memiliki pengetahuan baik dengan status gizi balita normal dan sebagian besar ibu dengan status balita tidak normal memiliki pengetahuan yang kurang ${ }^{16}$. Tingkat pengetahuan ibu tentang gizi yang tinggi dapat mempengaruhi pola makan balita dan akhirnya akan mempengaruhi status gizi balita. Jika pengetahuan ibu baik, maka ibu dapat memilih dan memberikan makan bagi balita baik dari segi kualitas maupun kuantitas yang dapat memenuhi angka kecukupan gizi yang dibutuhkan oleh balita sehingga dapat mempengaruhi status gizi balita tersebut.

Tingkat asupan zat gizi balita yang meliputi asupan energi, karbohidrat, protein dan lemak. Tingkat asupan zat gizi balita dilihat dengan menghitung asupan dan membandingkan dengan Angka Kecukupan Gizi (AKG) usia $1-3$ tahun yang dianjurkan. Menurut Gibson (2005) asupan energi, karbohidrat, protein dan lemak balita diklasifikasikan menjadi 2 bagian yaitu inadekuat $(<77 \%)$ dan adekuat $(\geq 77 \%)$.

Berdasarkan asupan energi balita, diketahui bahwa terdapat $63,8 \%$ balita yang memiliki asupan energi inadekuat dan sebesar $36,2 \%$ balita memiliki asupan energi adekuat. Jika dikelompokkan sesuai dengan status gizi balita usia 12-24 bulan, balita yang memiliki asupan energi inadekuat $(34,0 \%)$ dengan status gizi normal lebih banyak jika dibandingkan dengan balita yang memiliki status gizi tidak normal (29,8\%). Berdasarkan hasil uji chi square didapatkan nilai signifikansi 0,008 dengan $\alpha=0,05$. Kesimpulan yang dapat diambil yaitu terdapat hubungan asupan energi balita dengan status gizi balita (BB/U). Penelitian ini sejalan dengan penelitian yang menyebutkan bahwa terdapat hubungan asupan energi dengan status gizi balita ${ }^{17}$. Berdasarkan data penelitian menunjukkan bahwa balita dengan asupan energi kurang sebagian besar memiliki status gizi normal. Akibat yang ditimbulkan dari asupan energi yang kurang dari kebutuhan adalah status gizi balita tersebut dapat menurun ${ }^{18}$.

Berdasarkan asupan protein balita, $70,2 \%$ balita yang memiliki asupan protein adekuat dan $29,8 \%$ balita memiliki asupan protein yang inadekuat. Jika dikelompokkan sesuai dengan status gizi balita usia 12-24 bulan, balita yang memiliki asupan energi adekuat dengan status gizi normal (59,6\%) lebih banyak jika dibandingkan dengan balita yang memiliki status gizi tidak normal $(10,6 \%)$. Hasil analisis selanjutnya juga menunjukkan bahwa terdapat hubungan asupan protein dengan status gizi balita $(B B / U)(p=0,002<$ 0,050 ). Penelitian ini sejalan dengan penelitian Supriyanti (2015) yaitu terdapat hubungan asupan protein dengan status gizi balita $(\mathrm{BB} / \mathrm{U})$ 
dengan nilai $p=0,004(p<0,050)$. Hal ini juga sejalan dengan hasil penelitian di wilayah kerja Puskesmas Bungangan Kota Semarang yang menunjukkan bahwa semakin tinggi asupan energi dan protein maka status gizi balita semakin baik $^{19}$. Semakin rendah asupan protein balita maka akan semakin rendah status gizinya. Protein memiliki peran dalam pertumbuhan dan pemeliharaan jaringan, pembentukan senyawa tubuh, regulasi keseimbangan air dalam tubuh, pembentukan antibodi, dan transport zat gizi ${ }^{20}$.

Hasil penelitian menunjukkan bahwa nilai $p=0,024(p<0,050)$ yaitu terdapat hubungan asupan karbohidrat dengan status gizi balita (BB/U). Penelitian ini tidak sejalan dengan penelitian yang menunjukkan tidak ada hubungan asupan karbohidrat dengan status gizi balita ${ }^{21}$. Asupan karbohidrat pada balita sebagian besar inadekuat karena balita cenderung memiliki asupan karbohidrat seperti nasi yang sedikit. Hal tersebut dapat terjadi karena hasil recall 24 jam menunjukkan bahwa sebagian besar balita hanya mengonsumsi nasi sekitar 3-5 sendok makan saja setiap kali makan sehingga asupan karbohidrat pada balita sebagian besar inadekuat. Asupan karbohidrat yang adekuat mempengaruhi asupan energi secara keseluruhan karena berdasarkan anjuran bahwa $60 \%$ kebutuhan energi berasal dari sumber karbohidrat. Jika balita kekurangan karbohidrat maka dapat menimbulkan kekurangan energi dan akibatnya berat badan balita akan mengalami penurunan sehingga mempengaruhi status gizi balita $(B B / U)$ dan mengalami pertumbuhan yang terhambat.

Hasil penelitian menunjukkan bahwa niali $p=0,175(p>0,050)$ sehingga tidak terdapat hubungan asupan lemak dengan status gizi balita (BB/U). Penelitian ini sejalan dengan penelitian yang menyebutkan bahwa asupan lemak tidak memiliki hubungan dengan status gizi balita (BB/U), dengan nilai $p=0,498$ $(p>0,050)^{22}$. Asupan lemak balita usia 12-24 bulan sebagian besar kurang (70,2\%). Kurangnya asupan lemak yang dialami oleh balita tersebut balita mengonsumsi sayur dan buah yang lebih banyak direbus sehingga mengandung lemak yang sedikit. Tidak ada hubungan asupan lemak dengan status gizi balita $(\mathrm{BB} / \mathrm{U})$ pada penelitian ini karena lauk yang dikonsumsi balita juga memiliki kandungan lemak yang rendah contohnya mujair, wader dan bawal. Selain karena kurangnya lemak yang bersumber dari lauk, kandungan lemak yang terdapat pada susu yang dikonsumsi oleh balita tersebut tidak mencukupi kebutuhan lemak yang dianjurkan untuk balita.

\section{KESIMPULAN}

Dari penelitian ini dapat disimpulkan bahwa status gizi balita (BB/U) dipengaruhi oleh pengetahuan ibu tentang gizi dan asupan makan balita (energi, karbohidrat dan protein). Upaya untuk meningkatkan status gizi balita, sebaiknya meningkatkan pengetahuan ibu tentang gizi melalui penyuluhan pada ibu balita tentang pemilihan dan pengolahan makanan yang beragam dan bergizi seimbang. Selain itu, sebaiknya ibu meningkatkan asupan makan balita yang meliputi sumber energi, karbohidrat dan protein.

\section{ACKNOWLEDGEMENT}

Penulis mengucapkan terimakasih kepada: Badan Kesatuan Bangsa dan Politik (BaKesBangPol) Kota Surabaya, Dinas Kesehatan Kota Surabaya dan Puskesmas Tambak Wedi Surabaya yang telah memberikan izin untuk penelitian ini. Dosen pembimbing yang dengan sabar memberikan bimbingan. Dosen dan staff Program Studi IImu Gizi Fakultas Kesehatan Masyarakat Universitas Airlangga.

\section{REFERENSI}

1. Adriani, M., and Wirjatmadi, B. Peran Gizi dalam Siklus Kehidupan. Jakarta: Kencana Prenada Media Group. 2014.

2. Almatsier, S. Prinsip Dasar Ilmu Gizi. Jakarta: P.T Gramedia Pustaka Utana. 2009.

3. Supariasa, I.D.N., Fajar, I., Bakri, B. Penilaian Status Gizi. Jakarta: ECG. 2012.

4. Depkes RI. Pedoman Umum Pemberian (MP-ASI) Makanan Pendamping Air Susu Ibu Lokal. Jakarta: Depkes RI. 2006. 
5. Nugroho, A. H. Program Perbaikan Gizi Masyarakat di Jawa Timur. Bidang PPKM Dinkes Provinsi Jawa Timur. 2016.

6. Wahyuni, I. Hubungan Tingkat Pengetahuan Ibu tentang Gizi dengan Status Gizi Anak Balita di Desa Ngemplak Kecamatan Karangpandan Kabupaten Karanganyar. Skripsi. Surakarta: Universitas Sebelas Maret Surakarta. $2009 . \quad$ Tersedia di $<$ https://digilib.uns.ac.id/...=/Hubungantingkat-pengetahuan-ibu-tentang-gizidengan-s...> [2 Maret 2017]

7. Notoatmojo, S. IImu Kesehatan Masyarakat. Jakarta: Rineka Cipta. 2005.

8. Anggraeni, S. Hubungan antara Pengetahuan Ibu tentang Gizi, Pola Pemberian MP-ASI, Tingkat Asupan dengan Status Gizi Baduta BGM. Skripsi. Surabaya. Universitas Airlangga. 2013.

9. Labada, A. Hubungan Karakteristik Ibu dengan Status Gizi Balita yang Berkunjung di Puskesmas Bahu Manado. Jurnal Keperawatan 2016, [e-journal] 4 (1). $<$ http://ejournal.unsrat.ac.id/index.php/jk $\mathrm{p} /$ article/download/.../1148> [diakses tanggal 22 April 2017]

10. Liswati, E. M., Hubungan Karakteristik Ibu dengan Status Gizi Anak Balita yang Memiliki Jamkesmas di Desa Tegal Gizi Kecamatan Nogosari Kabupaten Boyolali [naskah publikasi]. Surakarta. Program Studi IImu Gizi Fakultas IImu Kesehatan Universitas Muhammadiyah Surakarta. 2016.

11. Suhendri, U. Faktor-faktor yang Berhubungan dengan Status Gizi Anak Dibawah Lima Tahun (BALITA) di Puskesmas Sepatan Kecamatan Sepatan Kabupaten Tangerang Tahun 2009. SKRIPSI. Universitas Islam Negeri Syarif Hidayatullah Jakarta. 2009. Tersedia di <http://repository.uinjkt.ac.id/dspace/ha ndle/123456789/2396> [22 April 2017]

12. Bashir, S. S. Effect of Maternal Literacy on Nutritional Status of Children Under 5 Years of Age in the Babban-Dodo Community Zaria City Northwest Nigeria. Annals of Nigerian Medicine Journal 2012. [e-journal] 6 (2). Tersedia di <http://www.anmjournal.com/text.asp?2
012/6/2/61/108110> [diakses tanggal 30 Maret 2017]

13. Odunze, I. Food Availability, Accessibility and Nutritional Status of Low Income Households of Selected Federal Tertiary Institutions in Kaduna State Nigeria 2016. International Research Journals, [ejournal] 7 (1). Tersedia di <http://www.interesjournals.org/AJFST> [diakses tanggal 12 Maret 2017]

14. Wardani, Y. Hubungan antara Asupan Makanan dan Status Kesadaran Gizi Keluarga dengan Status Gizi Balita di Wilayah Kerja Puskesmas Sewon I Bantul. KES MAS 2013, [e-journal] 6 (3). Tersedia di<http://media.neliti.com/media/publica tions/24918-ID-hubungan-antara-asupanmak... > [diakses tanggal 28 Maret 2017]

15. Yudi, H. Hubungan Faktor Sosial Budaya dengan Status Gizi Anak Usia 6-24 Bulan di Kecamatan Medan Area Kota Medan Tahun 2017. TESIS. Universitas Sumatera Utara Medan. 2008. Tersedia di <repository.usu.ac.id>bitstream shandle> [26 Juli 2017]

16. Notoatmojo, S. IImu Kesehatan Masyarakat. Jakarta: Rineka Cipta. 2005.

17. Handono, N. P. Hubungan Tingkat Pengetahuan pada Nutrisi, Pola Makan, dan Energi Tingkat Konsusi dengan Status Gizi Anak Usia Lima Tahun di Wilayah Kerja Puskesmas Selogiri, Wonogiri. JOM PSIK 2010. [e-journal] 1 (2). Tersedia di <http://download.portalgaruda.org/articl e.php?article $=186708 \&$ val $=6447 \&$ title $=\mathrm{Hu}$ bungan\%20pengetahuan\%20ibu\%20tenta ng\%20gizi\%20Dengan\%20status\%20gizi\% 20anaka\%20usia\%201-3\%20tahun> [diakses tanggal 21 April 2017]

18. Moehji, S. Ilmu Gizi Pengetahuan Dasar Ilmu Gizi. Jakarta: PT. Bhratara Niaga Media. 2009.

19. Rarastiti, C. N. HUbungan Karakteristik lbu, FrekuensiKehadiran Anak ke Posyandu, Asupan Energi dan Protein dengan Status Gizi Anak Usia 1-2 Tahun. Skripsi. Universitas Diponegoro Semarang. 2013.

20. Muchtadi, D. Pengantar IImu Gizi. Bandung: Alfabeta. 2009. 
21. Regar. Hubungan Kecukupan Asupan Energi dan Makronutrien dengan Status Gizi Anak Usia 5-7 Tahun di Kelurahan Kampung Melayu Jakarta Timur. Jurnal Kedokteran Universitas Indonesia 2013. [e-journal] 1 (3). Tersedia di<http://journal.ui.ac.id/index.php/eJKI/ article/view/3001/2460> [diakses tanggal 6 April 2017]
22. Adani, V., Pengestuti, D., Rahfiludin, Z. Hubungan Asupan Makanan (Karbohidrat, Protein dan Lemak) dengan Status Gizi Bayi dan Balita. Jurnal Kesehatan Masyarakat 2016; [e-journal] 4 (3). Tersedia di <http://ejournals1.undip.ac.id/index.php/jkm> [diakses tanggal 5 April 2017] 